\title{
Analisis Manajemen Pengawasan dan Pengendalian Penyalahgunaan Formalin di Dinas Kesehatan Kabupaten Tangerang
}

\author{
Hendri Hartati*
}

\begin{abstract}
Abstrak
Banyak industri makanan Tangerang ditemukan menggunakan bahan pengawet formalin. Tujuan penelitian ini mengetahui peranan Dinas Kesehatan (Dinkes) Kabuaten Tangerang mengawasi dan mengendalikan formalin pada makanan. Penelitian ini dilakukan pada Nopember 2006-Pebruari 2007. Dengan metode kualitatif wawancara mendalam dan penelusuran dokumen. Sumber data adalah Dinkes Kabupaten Tangerang dan Puskesmas terpilih. Pera responden adalah Kepala Dinkes Kabid Yankes; Kasi Pengawasan makanan dan minuman; Staf pelak-sana Dinkes dan Puskesmas. Hasil yang ditemukan meliputi pengawasan dan pengendalian formalin dilakukan oleh dinas kesehatan secara rutin sejak tahun 2004. Namun, program intensif ketika merebak issue kandungan formalin dalam makanan, tahun 2006. Masalah yang dihadapi: peraturan belum tersosialisasi, dana terbatas, tenaga wasdal terbatas dan tugas rangkap. Pemeriksaan sampel secara kuantitatif dilakukan di BPOM, pemeriksaan kualitatif mulai dilakukan tetapi masih terbatas kerena puskesmas belum punya alat. Material sudah mendukung pelaksanaan wasdal formalin. Jadwal kegiatan ada dan disusun di tingkat puskemas. Data tersedia tetapi tidak tersusun dalam sistem informasi. Buku panduan kegiatan belum ada. Faktor yang mendukung antara lain kerjasama lintas sektor; partisipasi laporan masyarakat, dan supervisi oleh POM/ Dinkes propinsi. Kabupaten Tanggerang Faktor yang menghambat adalah area kerja luas, sumberdaya dan faktor pendukung, iterbatas ndustri makanan (UKM), jasa boga, rumah makan dan pasar yang banyak. Perlu dilakukan upaya peningkatan sumberdaya dan faktor-faktor yang mendukung serta mengatasi hambatan yang ada.
\end{abstract}

Kata kunci : Pengawasan, pengendalian, formalin

\begin{abstract}
The district of Tangerang is a high risk area of the misuse of formaldehyde as food preservative. Researches show that many types of food are contaminated by formaldehyde. The aim of this study was to obtain in-depth information on the implementation, supervision and control of formaldehyde misuse managed by the Tangerang District Health Office. This study is a descriptive study using qualitative technique with District Health Office as analysis unit. In-depth interview technique and document analysis were used to collect data. The variables of this research were determined before the research conducted. The study showed that the process of management had not been successfully implemented in an intensive way except in the occasion when the issue was published extensively in the media. Non-intensive supervision and controlling happened due to some factors namely, lack of resources (regulation, money, personnel, laboratory, equipment, and guideline), non-routine inter-sector collaboration, and non-periodic supervision from province level. In order to achieve the optimal supervision and controlling activity, it is suggested that the resources and supporting factors should be enhanced through varied strategies.
\end{abstract}

Keywords : Supervision, controlling, formaldehyde 
Peran dinas kesehatan sangat penting khususnya dalam pengawasan dan pengendalian penggunaan Bahan Berbahaya dan Beracun (B3) salah satunya adalah formalin. Formalin ini menjadi masalah ketika disalahgunakan menjadi bahan pengawet makanan, padahal zat ini termasuk zat yang berbahaya bagi kesehatan manusia. Penggunaan formalin terlarang pada pengawetan makanan seperti tahu, mie, ayam, daging, ikan, baso serta ikan asap karena penggunaan pada makanan dapat merugikan kesehatan. Pada kadar 10 sampai 20 ppm menimbulkan batuk, rasa sesak di dada, dan rasa tertekan di kepala. Pada pemajanan 50-100 ppm atau diatasnya terjadi edema paru-paru, pneumonitis, atau kematian. Larutan formaldehid atau formalin ini juga dapat menimbulkan dermatitis. ${ }^{1}$ Penyalahgunaan formalin untuk makanan di Indonesia telah diteliti oleh badan POM pada bulan Desember 2005.2 Badan POM melakukan pengambilan sampling secara serial dan serentak di Bandar Lampung, Jakarta, Bandung, Semarang, Yogyakarta dan Makassar. Produk makanan yang diuji meliputi tahu, mie basah dan ikan yang berjumlah 761 sampel. Berdasarkan hasil uji laboratorium diperoleh temuan sebagai berikut:

Tabel 1. Penyalahgunaan Formalin pada Sampel Makanan di Indonesia Tahun 2005

\begin{tabular}{llll}
\hline & Mie Basah & Tahu & Ikan \\
\hline Jumlah Sampel & 213 & 290 & 258 \\
Memenuhi syarat & 76 & 193 & 190 \\
Tidak memenuhi syarat & 137 & 97 & 68 \\
$\%$ Tidak memenuhi syarat & $64.32 \%$ & $33.45 \%$ & $6.36 \%$ \\
\hline
\end{tabular}

Formalin sebagai pengawet makanan telah digunakan secara luas, padahal zat ini berbahaya bagi kesehatan manusia karena berpotensi karsinogenik. Pada percobaan binatang, formaldehid terbukti menyebabkan kanker. Pada konsentrasi di atas 0.1 ppm di udara, uapnya menimbulkan rasa pedih dimata, dan iritasi saluran pernapasan bagian atas serta kontraksi saluran pernafasan sehingga banyak sel leukosit yang masuk ke dalam paru-paru. Pada kadar 10 sampai 20 ppm menimbulkan batuk, rasa sesak di dada, rasa tertekan di kepala, dan palpasi. Pada pemajanan 50-100 ppm atau diatasnya terjadi edema paru-paru, pneumonitis, atau kematian. Larutan formaldehid atau formalin ini juga dapat menimbulkan dermatitis.

Penggunanan formalin ini dapat dicegah/dikontrol melalui pengawasan dan pengendalian penggunaan bahan tersebut oleh instansi kesehatan setempat (dinas kesehatan dan puskesmas) bekerjasama dengan sektor lain yang terkait serta melibatkan masyarakat dan swasta. Penggunaan formaldehid dalam pengawetan makanan di Kabupaten Tangerang dipengaruhi banyak faktor antara lain instansi kesehatan, masyarakat dan swasta. Banyak faktor yang mempengaruhi pelaksanaan pengawasan dan pengendalian penggunaan formalin antara lain kertersediaan dana. Kegiatan pengawasan dan pengendalian penggunaan formalin akan berdampak penting bagi status kesehatan. Penelitian ini bertujuan untuk mengetahui peranan Dinas Kesehatan Kabupaten Tangerang dalam manajemen pengawasan dan pengendalian formalin untuk mereduksi penggunaan formalin pada makanan.

\section{Metode}

Penelitian ini menggunakan metode analisis deskriptif dan teknik kualitatif. Teknik kualitatif yang digunakan adalah kombinasi wawancara mendalam dengan penelusuran dokumen. Teknik kualitatif yang digunakan dalam penelitian ini adalah teknik kualitatif yang terarah yang membatasi dan menentukan variabel yang diteliti sebelum penelitian dilaksanakan. Data yang dikumpulkan adalah data primer dan sekunder tentang manajemen pengawasan dan pengendalian penggunaan formalin pada makanan. Penelitian dilakukan di Kabupaten Tangerang, di wilayah kerja Dinas kesehatan Kabupaten Tangerang pada Bulan Nopember 2006 - Pebruari 2007. Sumber data adalah Dinas Kesehatan Kabupaten Tangerang dan Puskesmas terpilih di wilayah Kabupaten Tangerang. Pemilihan sampel dilakukan secara "purposif" berdasarkan kesesuaian dengan tujuan penelitian dan masalah penelitian. Informan penelitian dipilih berdasarkan kriteria kesesuaian dan kecukupan. Informan yang ditetapkan dalam penelitian dapat dilihat pada tabel 2 .

Pengumpulan data dilakukan di Dinas Kesehatan Kabupaten Tangerang dengan cara wawancara mendalam dan penelusuran data sekunder. Pengumpulan data ini dilakukan pada periode Nopember 2006 sampai dengan Pebruari 2007. Instrumen pengumpulan data yang primer digunakan adalah daftar/pedoman wawancara mendalam yang disusun berdasarkan kerangka konsep penelitian. Pengolahan data dilakukan secara manual oleh peneliti dengan langkah kegiatan yang meliputi pemindahkan data dari hasil wawancara terbuka setiap responden dari pita rekaman ke dalam transkrip lengkap tanpa membuat kesimpulan. Selanjutnya, melakukan reduksi data dengan memilih data yang relevan dengan variabel yang diteliti. Kemudian, dibuat ringkasan data dalam bentuk matriks atau tabel dari hasil wawancara mendalam. Sedangkan data dari hasil penelitian dokumen dicatat dalam lembar pencatat berisi kategori utama, selanjutnya dikelompokkan dalam kategori yang telah diberi kode sesuai variabel yang diteliti. Selanjutnya dilakukan triangulasi sumber dengan membandingkan jawaban antar informan untuk melakukan cross-check sehingga diperoleh kecocokkan dan kesim- 
Tabel 2. Informan dan topik wawancara

\begin{tabular}{|c|c|c|c|}
\hline Area Pengukuran & Informan & $\begin{array}{l}\text { Faktor Internal } \\
\text { (Sumber daya) }\end{array}$ & $\begin{array}{l}\text { Mekanisme Pengawasan \& } \\
\text { pengendalian formalin }\end{array}$ \\
\hline $\begin{array}{l}\text { Dinkes Kab. Tangerang \& beberapa } \\
\text { puskesmas terpilih sebagai unit pelak- } \\
\text { sana Dinkes }\end{array}$ & $\begin{array}{l}\text { Kepala Dinkes } \\
\text { Kabid Yankes } \\
\text { Kasi Pengawasan makanan \& } \\
\text { minuman } \\
\text { Staf pelaksana Dinkes dan } \\
\text { Puskesmas }\end{array}$ & $\begin{array}{l}\text { - Regulasi } \\
\text { - Anggaran/dana } \\
\text { - Tenaga/SDM } \\
\text { - Material } \\
\text { - Skedul kegiatan } \\
\text { - pengawasan formalin } \\
\text { - Buku pedoman } \\
\text { - Sarana/Lab } \\
\text { - Data } \\
\text { Faktor Eksternal } \\
\text { Koordinasi lintas sektor } \\
\text { Supervisi } \\
\text { Partisipasi masyarakat dan } \\
\text { Area kerja }\end{array}$ & $\begin{array}{l}\text {-Tujuan kegiatan } \\
\text {-Target Kegiatan } \\
\text {-Peran Dinkes } \\
\text {-Pelaksanaan Kegiatan }\end{array}$ \\
\hline
\end{tabular}

pulan jawaban.

\section{Hasil}

Di Kota Tanggerang, pengendalian penggunaan formalin dilakukan oleh Dinas Kesehatan Kabupaten Tangerang berkoordinasi dengan Diperindag, dinas perikanan, UPTD pasar, dan unsur pemda lainnya. Selama ini, menurut beberapa informan, pengawasan dan pengendalian formalin dilakukan dalam bentuk sidak dan pemeriksaan sampel makanan pada saat terjadi keresahan masyarakat. Bukan kegiatan lain seperti sosialisasi jenis dan tempat mendapatkan bahan pengawet pengganti formalin. Kegiatan sistem wasdal berupa verifikasi, observasi, analisis, evaluasi, investigasi, wawancara dengan menggunakan daftar periksa, penelusuran dokumen, kuesioner, dan peninjauan fisik. Sesuai dengan hasil penelitian bahwa instrumen wasdal berupa cheklist yang berlaku tepat dan dan akurat sehingga dapat digunakan oleh setiap orang, metode dengan kunjungan bersama dalam satu tim teknis secara terpadu. ${ }^{3}$

Sasaran kegiatan pengawasan dan pengendalian formalin yang dilakukan oleh Dinas Kesehatan Kabupaten Tangerang adalah industri tahu, baso dan mie. Untuk usaha penangkapan ikan dan industri ikan asin tidak diawasi oleh dinas kesehatan, tetapi ikan yang dijual di pasar diawasi oleh dinas kesehatan. Belum seluruh sasaran pengawasan dan pengendalian tercapai karena jumlah sasaran banyak, meliputi 40 puskesmas binaan, 45 industri rumah tangga, 38 catering, 42 industri makanan dan minuman, dan beberapa pasar tradisional dan modern. Cakupan pengawasan dan pengendalian yang dilakukan dinkes kabupaten Tangerang belum luas dan intensif dibandingkan pelaksanaan kegiatan lain.

Ketersediaan dan kecukupan sumber daya merupakan faktor penentu yang penting dalam mekanisme pe- ngawasan dan pengendalian. Semakin kecilnya sumberdaya akan semakin sulit melaksanakan kegiatan pengawasan dan pengendalian demikian pula sebaliknya. Dinkes Kabupaten Tangerang harus terus memaksimalkan fungsinya sebagai pengawas dan pengendalian penggunaan formalin sehingga dapat melindungi kesehatan konsumen. Namun, dari hasil penelitian diketahui bahwa secara umum sumber daya pengawasan dan pengendalian tersebut terbatas. Hal tersebut berimplikasi pada pelaksanaan wasdal yang tidak optimal, penelitian tentang kajian pembinaan, pengawasan dan pengendalian sarana pelayanan kesehatan swasta di Kabupaten Bekasi yang dilakukan sebelumnya menemukan bahwa pembinaan, pengawasan dan pengendalian tidak berjalan sesuai dengan peraturan karena keterbatasan sumberdaya. ${ }^{4}$ Hasil tersebut diharapkan dapat menjadi pertimbangan untuk perbaikan sumberdaya wasdal penyalahgunaan formalin karena menurut perbaikan sumberdaya termasuk juga dalam bagian pengendalian. ${ }^{5}$

Regulasi atau peraturan yang terkait dengan program pengawasan dan pengendalian formalin sangat diperlukan untuk mendukung pelaksanaan kegiatan di lapangan. Meskipun peraturan perundangan tentang formalin telah banyak tersedia, tetapi hanya Permenkes yang diketahui dan dijadikan acuan kegiatan oleh petugas wasdal penggunaan formalin di lapangan. Selain itu, petunjuk pelaksanaan, petunjuk teknis kegiatan wasdal penggunaan formalin pada makanan ternyata belum diketahui oleh para petugas Dinas Kesehatan Kabupaten Tangerang. Juklak atau Juknis yang tersedia adalah Juklak penyuluhan makanan dan minuman yang berbentuk modul penyuluhan serta Juklak dan Juknis pembuatan sertifikasi sehat untuk industri makanan. Sedangkan Juklak atau Juknis yang khusus untuk pengawasan penggunaan formalin di Dinas Kesehatan 
Kabupaten Tangerang belum tersedia. Untuk sementara, kegiatan pengawasan dan pengendalian dapat berjalan meskipun tanpa Juklak dan Juknis yang jelas. Namun, untuk memperkuat manajemen program pengawasan dan pengendalian formalin Juklak/Juknis yang jelas untuk petugas lapangan sangat diperlukan. Untuk di tingkat puskesmas, kegiatan pembinaan industri rumah tangga, pasar dan rumah makan mengacu pada Juklak dan Juknis sanitasi karena Juklak dan Juknis untuk B3 belum ada. Implikasi ketiadaan juklak tersebut adalah bahwa kegiatan wasdal ini belum berjalan secara optimal.

Di seksi pengawasan makanan dan minuman ada 12 orang petugas, tetapi yang terlibat dalam kegiatan pengawasan dan pengendalian formalin hanya empat orang. Staf lain yang bertugas pada pengawasan obat di apotik dan toko obat serta persediaan obat di gudang obat dinas kesehatan. Pengelola program pengawasan dan pengendalian formalin di Dinas Kesehatan Kabupaten Tangerang yang berjumlah empat orang tersebut dirasakan masih kurang, sehingga pengelolaan program masih menjadi beban yang berat. Berdasarkan latar belakang pendidikan, terdiri dari apoteker, kesehatan lingkungan, sosial dan farmasi, sehingga dipandang mampu menjalankan tugas mereka. Setiap petugas mengacu pada tupoksi seksi pengawasan makanan dan minuman serta kesepakatan pembagian tugas di dalam seksi. Kegiatan pengawasan dan pengendalian formalin sudah terlaksana, tetapi belum dapat mencakup semua area kerja Dinkes karena kerterbatasan jumlah tenaga yang masingmasing memiliki tugas rangkap yang lain.

Dari hasil penelitian diketahui bahwa para petugas lapangan tersebut bukan tenaga khusus pengawasan formalin, tetapi mereka telah dilatih untuk dapat mengerjakan tugas tersebut sesuai dengan ketentuan standard laboratorium yang berlaku. ${ }^{6}$ Hasil penelitian ini juga mengungkapkan bahwa petugas dengan latar belakang pendidikan sanitasi merasa perlu pelatihan khusus pengawasan dan pengendalian formalin. Hal tersebut penting karena berpengaruh terhadap kinerja petugas wasdal sesuai dengan hasil penelitian sebelumnya. Sanitarian yang tidak pernah mengikuti pelatihan cenderung menampilkan kinerja buruk 2.1 kali lebih besar daripada yang pernah ikut pelatihan.

Di Dinas Kesehatan Kabupaten Tangerang, material pendukung pelaksanaan program pengawasan dan pengendalian formalin telah tersedia, meskipun masih digunakan secara bergantian. Namun, tidak menghambat pelaksanaan masing-masing kegiatan. Penelitian ini menemukan bahwa jadwal pengawasan dan pengendalian penggunaan formalin pada makanan telah dibuat secara bersama-sama dan dipatuhi oleh setiap petugas. Jadwal tersebut dibuat di tingkat kabupaten dan di tiap puskesmas, sehingga masing-masing petugas bekerja sesuai dengan jadwal yang telah disepakati. Data tentang jumlah industri, lokasi dan pasar yang harus dibina serta data hasil pemeriksaan sampel telah tersedia di Dinas Kesehatan Kabupaten Tangerang. Data tersebut berguna untuk menunjukkan dugaan keberadaan formalin dan alur perjalanan formalin hingga sampai di makanan.

Partisipasi masyarakat dalam pengawasan dan pengendalian formalin baru pada tahap pelaporan yang masih terbatas karena pengetahuan masyarakat tentang ciriciri produk yang mengandung formalin yang rendah. Dukungan dalam bentuk lain belum ada, meskipun demikian petugas sanitasi puskesmas menganggap bahwa partisipasi masyarakat tersebut sudah mendukung wasdal. BPOM pusat sangat berperan dalam kegiatan supervisi pengawasan dan pengendalian formalin. Selain itu, POM Dinkes Bagian makanan dan minuman juga telah berperan dalam supervisi yang lebih bersifat koordinasi.

Area kerja wasdal Dinas Kesehatan Kabupaten Tangerang cukup luas antara lain meliputi Tempat Pengolah Makanan (warung makan, restoran dan jasa boga, industri kecil, dan pedagang di pasar). Hal tersebut menjadi beban kerja yang cukup berat bagi petugas pengawasan formalin sedangkan tenaga yang terbatas membuat jangkauan ke seluruh area kerja menjadi terbatas.

\section{Pembahasan}

Pengawasan dan pengendalian penggunaan formalin pada makanan merupakan faktor yang penting karena kebutuhan makanan yang meningkat diikuti dengan, kebutuhan teknologi pengawetan makanan yang efisien dan meningkat pula. Tanpa pengawasan, industri dan pengolah makanan cenderung menggunakan bahan pengawet yang berbahaya seperti formalin dan boraks. Penggunaan bahan berbahaya tersebut dapat disebabkan oleh ketidaktahuan tentang dampak bahan pengawet dalam bentuk keracunan kronis akibat dosis kecil yang kumulatif atau keracunan akut dalam dosis besar. Formalin sangat mudah diserap melalui saluran pernafasan dan pencernaan. Pada penggunaan jangka panjang dapat berakibat buruk pada organ tubuh, seperti kerusakan hati dan ginjal. Formalin sering digunakan karena harganya yang murah dan mudah dijangkau masyarakat. Keberadaan formalin dalam beberapa jenis makanan bukan hal baru. Namun, informasi bahaya dan kesulitan membedakan produk yang diawetkan dengan formalin menjadi penyebab kelangsungan konsumsi makanan berformalin oleh masyarakat. Perilaku konsumen yang memilih produk yang awet dan harga yang murah diduga juga menjadi penyebab penggunaan formalin pada makanan.

Dalam era desentralisasi dan otonomi daerah, peranan kabupaten/kota semakin menjadi penting dan menentukan dalam merencanakan dan melaksanakan program kesehatan. Khusus untuk pengendalian B3, daerah harus mempunyai kemampuan untuk melaksanakan pe- 
ngendalian pencemaran bahan tersebut. 6 Mengacu pada tupoksi Dinkes tingkat kabupaten ada 6 wewenang dan 13 fungsi pengawasan dan pengendalian penggunaan bahan berbahaya. Dinas Kesehatan berperan sebagai pengawas, pembuat keputusan dan melakukan tindakan jika ditemukan penggunaan formalin pada makanan. Dalam melaksanakan pengawasan, dinas kesehatan dibantu oleh puskesmas memeriksa sampel, memberikan penyuluhan dan melakukan pemantauan.

Sebagai perbandingan, kegiatan pemantauan pestisida (test cholinesterase) pada 250 orang petani, pada tahun 2004 dan 2005 dilakukan di 10 kecamatan. Inspeksi sanitasi sarana air bersih (2000 sarana), pengambilan, pengiriman dan pemeriksaan sampel air bersih untuk pemeriksaan bakteriologi (240 sampel) dan fisika/kimia sebanyak 60 sampel serta penyuluhan pencegahan penyakit melalui air (6 kecamatan yang meliputi 20 desa). ${ }^{7}$ Kegiatan tersebut belum dilakukan secara intensif sehingga hasil yang didapat belum optimal. Pengawasan memerlukan saat yang tepat, intensif dan relevan sehingga mekanisme kontrol dapat mendeteksikan penyimpangan secara dini sehingga jeda waktu antara deteksi dan tindakan koreksi awal singkat. Jika memungkinkan, mekanisme kontrol seharusnya dilakukan secara rutin tidak hanya inspeksi khusus yang dilakukan pada waktu tertentu. ${ }^{8}$

Meskipun demikian, output kegiatan pengawasan dan pengendalian penggunaan formalin pada makanan tersebut sudah dapat dirasakan. Output kegiatan tersebut adalah peningkatan pengetahuan produsen tentang bahaya formalin. Selain itu, produsen yang pernah menggunakan formalin telah menghentikan penggunaan formalin berkat pengawasan dan pembinaan yang dilakukan dinas kesehatan kabupaten Tangerang. Sedangkan dampak pengendalian adalah terjaganya kualitas produk makanan yang dapat meningkatkan status kesehatan masyarakat. Saat ini persoalan makanan berformalin sudah mereda di masyarakat dan kesadaran pedagang dan produsen akan bahaya pemakaian formalin sudah tumbuh. Namun, hal ini tidak boleh dijadikan alasan untuk melemahnya pengawasan dan pengendalian formalin.

Pengendalian penggunaan formalin dalam makanan telah diatur dalam peraturan dan perundang-undangan di Indonesia. Pengendalian pencemaran dan resiko akibat pencemaran formalin telah diatur dalam beberapa peraturan dan perundang-undangan baik secara eksplisit maupun implisit. ${ }^{6}$ Sebagai contoh, pada UU No. 23 Tahun 1992 tentang kesehatan, pasal 21 berisi tentang pengamanan makanan dan minuman dilakukan sesuai standard jika tidak akan ditindak mulai dari larangan beredar, ditarik dari peredaran dan dimusnahkan. Formalin merupakan salah satu bahan tambahan pangan (BTP) yang dilarang digunakan dalam makanan menurut peraturan Menteri Kesehatan (Menkes) Nomor 1168/
Menkes/PER/X/1999. Selanjutnya, tata niaga bahkan diatur dengan Surat Keputusan Menteri Perindustrian dan Perdagangan Nomor 254/MPP/KEP/7/2000. Selain itu, Menteri perdagangan telah menerbitkan peraturan menteri Perdagangan (Permendag) No. 04/M-DAG/ PER/ 2/2006 tanggal 16 Februari 2006 tentang distribusi dan pengawasan bahan berbahaya. Impor zat formalin hanya dapat dilakukan oleh para importir produsen yang diakui Dirjen Perdagangan Luar Negeri. Selain itu, PP No. 74 Tahun 2001 tentang pengelolaan Bahan Berbahaya dan Beracun dapat juga dijadikan bahan referensi bagaimana mengawasi dan melaporkan bahan berbahaya.

Menurut Menteri Perindustrian, ada empat langkah yang akan dilakukan pemerintah berhubungan dengan penyalahgunaan formalin yaitu: Pertama, penyuluhan kepada masyarakat, produsen khususnya UKM, dan produsen besar pemakai formalin. Kedua, pengawasan peredaran, produksi yang ditujukan kepada produsen dan importir. Ketiga, tindakan hukum terhadap para pelanggar. Keempat, melindungi industri kecil menengah dari penyalahgunaan zat berbahaya, bukan hanya formalin. ${ }^{11}$

Berdasarkan tugas dan fungsi Dinas kesehatan dalam Pengendalian Pencemaran B3 dari perspektif manajemen berarti Dinas Kesehatan juga berfungsi menyusun anggaran. ${ }^{6}$ Dinas kesehatan telah menyusun dan mengajukan anggaran secara global untuk pengawasan dan minuman (tidak terbatas pada kegiatan pengawasan dan pengendalian formalin). Dana yang disetujui tergantung pada kemampuan dan prioritas pemerintah daerah setempat. Penelitian ini menemukan bahwa kemampuan pemerintah daerah membiayai program kesehatan cukup besar, tetapi dana untuk pengawasan dan pengendalian formalin yang tercakup dalam program pengawasan makanan dan minuman yang diusulkan tidak seluruhnya disetujui, sehingga jumlah dana yang diterima masih terbatas.

Kegiatan pengawasan dan pengendalian formalin mengacu pada modul/buku pedoman yang disusun berdasarkan materi dalam pelatihan-pelatihan terkait makanan dan minuman. Namun, modul pelatihan yang tersedia belum secara spesifik membahas tentang formalin. Selama ini para petugas di dinas kesehatan Kabupaten Tangerang berusaha mendapatkan informasi tentang pengawasan dan pengendalian penyalahgunaan formalin dari berbagai sumber, antara lain pelatihan, koran dan materi pembinaan. Tingkat pengetahuan petugas sangat penting karena akan berdampak pada kinerja mereka. Sanitarian yang tidak mempunyai panduan kerja berisiko 2.5 kali lebih besar untuk berkinerja buruk daripada yang mempunyai pedoman kerja. ${ }^{10}$

Data yang dikumpulkan seksi pengawasan makanan dan minuman Dinkes Kabupaten Tangerang sudah sesuai dengan anjuran ditjen PP \& PL, ${ }^{6}$ bahwa data bahan yang membahayakan kesehatan masyarakat dan 
dicurigai telah terjadi pemajanan dan merupakan prioritas kesehatan masyarakat, harus dikumpulkan melalui program pemantauan. Data yang telah dihimpun tersebut dapat berguna saat evaluasi program.

Dalam pengawasan dan pengendalian formalin sangat diperlukan koordinasi lintas sektor. Menurut Ditjen PP\&PL dalam pemeriksaan bahan berbahaya harus melakukan pencarian informasi tentang kegiatan pemantauan bahan berbahaya tersebut bersama instansi lain guna menjalin kerjasama secara efisien dan sinergi. Pada penelitian ini, Dinas Kesehatan Kabupaten Tangerang telah menjalin kerjasama dengan dinas perindustrian dan perdagangan (Diperindag), UPTD (Unit Pelaksana Teknis Daerah) Pasar, Dinas perikanan dan peternakan dan Balai Besar POM. Namun, kerjasama lintas sektor tersebut belum terjalin baik, kecuali pada saat pemberitaan formalin yang gencar di media. Rapat koordinasi yang dilakukan terlaksana atas instruksi pemda, sedangkan sebagai kegiatan rutinnya belum terlaksana. Kerjasama dan koordinasi tersebut juga mengalami hambatan, karena penyesuaian waktu, mengingat masing-masing dinas punya tupoksi masing-masing.

\section{Kesimpulan}

Kegiatan pengawasan dan pengendalian penyalahgunaan formalin sebagai pengawet makanan di wilayah Kabupaten Tangerang telah dilakukan oleh Dinas Kesehatan Kabupaten Tangerang secara rutin sejak tahun 2004. Namun, kegiatan ini belum intensif kecuali ketika ada isu pada tahun 2006 ada isu kandungan formalin pada makanan. Sumberdaya dan faktor pendukung program pengawasan dan pengendalian formalin tersebut masih terbatas. Faktor lain yang mendukung kegiatan antara lain adalah : 1) kerjasama lintas sektor meliputi kepolisian, BPOM, diperindag, dinas pertanian dan peternakan, UPTD Pasar, dan Dinkes. Kegiatan tersebut sudah ada, tetapi tidak berjalan secara rutin (tidak ada dalam rencana kerja). 2) partisipasi masyarakat telah ada tetapi hanya sebatas pelaporan. 3) Supervisi khusus untuk formalin yang tidak terjadwal hanya dilakukan jika ada kejadian tertentu. Supervisi yang dilakukan POM/ dinkes propinsi lebih bersifat monitoring. Namun supervisi ini dinilai sudah bermanfaat dalam meningkatkan kinerja petugas di dinkes dan puskesmas di wilayah Kabupaten Tangerang. Area kerja dinas kesehatan Kabupaten Tangerang yang sangat luas membuat kegiatan ini tidak dapat dilakukan secara intensif jika hanya mengandalkan sumberdaya yang tersedia saat ini.

\section{Saran}

Pemda diharapkan dapat membentuk tim satgas pengawasan makanan berformalin yang mencakup kepolisian, BPOM, diperindag, dinas pertanian dan peterna- kan, UPTD Pasar dan Dinkes yang melakukan kegiatan pengawasan dan pengendalian secara berkala tidak hanya secara insidentil ketika ada issue kandungan formalin pada makanan merebak di media massa. Hal tersebut mengingat tempat pengolahan makanan yang banyak, antara lain meliputi industri, pasar tradisional/modern, jasa boga, dan restoran/warung makan yang beresiko tercemar formalin. Pemda juga perlu meningkatkan kapasitas Labkesda agar dapat memeriksa kandungan formalin dan zat berbahaya yang lain pada makanan, sehingga dapat memperpendek waktu pemeriksaan. Pemda juga diharapkan dapat mengembangkan jumlah dan kualitas petugas wasdal di dinas terkait khususnya di dinas kesehatan sesuai dengan wewenang rekrutmen dan penempatan yang ada di tangan pemda.

Selain itu, kewenangan mengembangkan sistem imbalan dan sangsi bagi perusahaan dan petugas yang diberikan, tidak terbatas hanya pada kepolisian, tetapi juga kepada seluruh tim Dinkes yang mempunyai rencana pengembangan staf berupa penambahan jumlah petugas dengan kualifikasi yang dibutuhkan. Untuk itu, perlu upaya peningkatan pengetahuan dan keterampilan melalui pelatihan dan penyediaan buku panduan bagi petugas teknis. Selain itu, Dinkes perlu meningkatkan frekuensi supervisi. Untuk mengambil sampel, perlu pengadaan alat tes kualitatif formalin untuk petugas wasdal. Frekuensi dan kualitas kerjasama lintas sektor perlu ditingkatkan antara lain dengan cara membuat sistem informasi lintas sektor, semua sektor terkait dapat menyesuaikan berbagai program sehingga tidak tumpang tindih. Selain itu, Dinas kesehatan perlu diberi wewenang memberi sanksi sampai mencabut ijin usaha/menutup dan menarik produk yang tercemar formalin.

Puskesmas perlu meningkatkan frekuensi pengawasan dan pengendalian pada industri, jasa boga, pasar maupun tempat produksi dan pengolahan makanan di sekitar wilayah kerja puskesmas. Frekuensi supervisi terhadap dinas kesehatan kabupaten/kota di Propinsi Banten perlu ditingkatkan. Partisipasi masyarakat hendaknya tidak terbatas pada pelaporan tetapi juga pada upaya meningkatkan pengetahuan tentang formalin dan kewaspadaan mengkonsumsi makanan. Produsen/pedagang makanan disarankan tidak menggunakan pengawet formalin. Mereka wajib mencantumkan label "bebas formalin" pada setiap kemasan produk yang diproduksi.

Penelitian serupa perlu dilakukan di Dinkes yang lain, sehingga pelaksanaan pengawasan dan pengendalian (Wasdal) dapat dibandingkan. Jika memungkinkan, dilakukan penelitian yang lebih luas mencakup semua unsur lintas sektor. Juga perlu penelitian lanjutan tentang variabel yang berpengaruh terhadap pengawasan dan pengendalian serta penelitian teknologi pengawetan makanan yang aman dan efisien. 


\section{Daftar Pustaka}

1. Depkes RI. (2006). Pedoman Manajemen Risiko Lingkungan Aspek Kimia/ B3, Tingkat Propinsi, 2006

2. Badan POM RI (2006). Press release Keterangan Pers Badan POM Nomor: KH.00.01.1.241.002 tentang formalin untuk pengawet mie basah, tahu dan ikan., 3 january 2006

3. Noerdin, Zoelkarnaen (2001). Rancangan Sistem Pengawasan dan Pengendalian Dinas Kesehatan dan Kesejahteraan Dalam Pelaksanaan Desentralisasi Program Kesehatan Tingkat Kecamatan/Puskesmas Studi Kasus di Kabupaten Musi Rawas (tesis) FKMUI, Yakarta

4. Soleh, Mohammad (1997). Kajian tentang Pembinaan, Pengawasan \& Pengendalian Sarana Pelayanan Kesehatan Swasta di Kab. DT II Bekasi Tahun 1997 (Tesis) FKM UI, Yakarta
5. WHO (1997). Guidelines For Poison Control, Geneva, 1997

6. Ditjen P2M \& PLP (1998). Pedoman Pembinaan dan Pengawasan Sanitasi Makanan Untuk Petugas Sanitarian Puskesmas. 1998

7. Dinas Kesehatan Kabupaten Tangerang. (2004). Profil Kesehatan Kabupaten Tangerang. 2004

8. Liebler, Joan Gratto et all (1992). Management Principles for Health Professionals, Aspen Publisher, 1992

9. Media industri (2006). Penyalahgunaan formalin dan peran pemerintah, edisi no 21.III.2006

10. Aini, M.A (2003). Analisis Kinerja Sanitarian Puskesmas dalam Pelaksanaan Pengawasan Koalitas Air Bersih di Kota Palembang Tahun 2003 